\title{
JARINGAN SOSIAL DAN STRATEGI ADAPTASI TENAGA KERJA MIGRAN ASAL LAMPUNG DI DESA JAYAMUKTI, KECAMATAN CIKARANG PUSAT, KABUPATEN BEKASI, PROVINSI JAWA BARAT
}

\author{
Social Networks and Adaptation Strategy of Migrant From Lampung In The Village of \\ Jayamukti, Center Cikarang Subdistrict, Bekasi District, West Java
}

\author{
Yessi Marga Safitri*) dan Ekawati Sri Wahyuni
}

Departemen Sains Komunikasi dan Pengembangan Masyarakat, Fakultas Ekologi Manusia, IPB

\begin{abstract}
Population growth rate that has increased rapidly in the recent years has made problems on labor matter. Population growth that was not supported by the increase of resources and employment opportunities would increase the number of unemployment. This condition would finally stimulate people to migrate. Population mobility influence by push factors from origins, among of them are limited number and kind of work and also is by pull factors in destination areas, such as more employment opportunities. The phenomenon of population mobility in Indonesia commonly form a cycle where the rich migrants, economically and socially, will persuade their family, relatives or friends to join the migration. The different situation and condition on destination areas forced them to adapt as survival strategy. Social networks is very important for migrant in the destination areas.
\end{abstract}

Keywords: adaptation, population mobility/migration, social networking

\begin{abstract}
ABSTRAK
Tingkat pertumbuhan penduduk meningkat secara cepat pada beberapa tahun terakhir menimbulkan permasalahan pada ketenagakerjaan. Pertumbuhan penduduk yang tidak didukung dengan peningkatan sumberdaya dan lapangan pekerjaan menambah jumlah pengangguran. Kondisi tersebut memacu penduduk untuk melakukan migrasi. Perpindahan penduduk dipengaruhi oleh faktor pendorong dari daerah asal, diantaranya yakni terbatasnya pekerjaan dan juga faktor penarik dari daerah tujuan, salah satunya lapangan pekerjaan yang lebih banyak. Fenomena perpindahan penduduk di Indonesia umumnya membentuk siklus dimana migran yang kaya secara ekonomi dan sosial akan memengaruhi keluarga mereka, saudara atau teman untuk ikut bermigrasi. Situasi yang berbeda dan kondisi pada daerah tujuan mendorong mereka untuk beradaptasi sebagai strategi bertahan hidup. Jaringan sosial sangat penting bagi para migran di daerah tujuan.
\end{abstract}

Kata kunci : adaptasi, jaringan sosial, perpindahan penduduk/migrasi

\section{PENDAHULUAN}

\section{Latar Belakang}

Kependudukan merupakan variabel penting dalam proses pembangunan suatu negara, namun kependudukan akan menimbulkan permasalahan apabila pertumbuhannya tidak dikendalikan. Salah satu permasalahan kependudukan di Indonesia adalah tingginya tingkat pengangguran akibat pesatnya pertumbuhan penduduk yang tidak didukung oleh pertambahan lapangan pekerjaan. Hal ini menimbulkan adanya ketidakseimbangan antara permintaan dan penawaran dalam pasar tenaga kerja, di mana penawaran tenaga kerja jauh lebih tinggi daripada permintaan yang ada. Mobilitas penduduk diyakini sebagai alternatif masyarakat untuk menunjang kehidupan mereka. Tujuan utama dari mobilitas ini adalah untuk meningkatkan kualitas hidup masyarakat sehingga menuntut mereka untuk mencari penghidupan yang lebih baik di lokasi yang juga lebih baik dalam hal penyediaan lapangan pekerjaan (Safrida, 2008). Oleh sebab itu, mobilitas penduduk yang umum terjadi terkait keterbatasan lapangan pekerjaan adalah migrasi dari desa ke kota karena pekerjaan di desa lebih terbatas dibandingkan kota, baik dari segi jenis maupun jumlah pekerjaan.

Di Indonesia, migrasi ketenagakerjaan memiliki pola yang umumnya berupa siklus di mana migran yang telah lama bermigrasi dan merasa kondisi sosial ekonominya sudah cukup stabil akan membawa migran baru yang akan mengikuti jejaknya untuk bermigrasi. Umumnya migran baru adalah tetangga, teman atau keluarga migran terdahulu. Meskipun begitu, untuk mendapat pekerjaan 
di kota tidaklah mudah. Tingginya migrasi penduduk dari desa ke kota membuat persaingan antar sesama migran juga semakin tinggi. Selain harus bersaing dalam mencari pekerjaan, migran juga harus beradaptasi dengan kondisi kota tujuan. Berdasarkan teori, lingkungan dan interaksi masyarakat yang ada di dalamnya membentuk kebudayaan (Haryono). Hal ini mengindikasikan bahwa kebudayaan kota berbeda dengan kebudayaan desa, di mana kebudayaan kota dianggap relatif maju dan modern dibandingkan budaya desa yang relatif sederhana. Untuk dapat bertahan hidup dan memperoleh kesejahteraan di daerah tujuan dibutuhkan strategi adaptasi. Umumnya strategi adaptasi yang diterapkan migran terdiri atas adaptasi sosial dan adaptasi ekonomi. Adaptasi sosial dilakukan untuk mencapai kehidupan sosial yang stabil dan adaptasi ekonomi dilakukan untuk memapankan pekerjaan dalam rangka mencapai kesejahteraan. Meskipun begitu, dalam proses adaptasinya tidak tampak apakah setelah bermigrasi migran memprioritaskan kehidupan sosial yang stabil lebih dahulu atau memprioritaskan kemapanan pekerjaan terlebih dahulu. Migran terdahulu, khususnya yang ikut berperan dalam proses migrasi migran baru, merupakan jaringan sosial migran baru di daerah tujuan. Mereka memiliki peran untuk membantu migran baru dalam beradaptasi.

\section{Masalah Penelitian}

Berdasarkan latar belakang, masalah yang perlu diteliti yaitu:

1. Bagaimana strategi adaptasi yang diterapkan migran di daerah tujuan?

2. Apakah migran mengutamakan kehidupan sosial yang stabil atau mengutamakan kemapanan pekerjaan?

3. Bagaimana peran jaringan sosial dalam adaptasi migran di daerah tujuan?

\section{Tujuan Penelitian}

Tujuan yang ingin dicapai melalui penelitian ini adalah:

1. Menganalisis strategi adaptasi yang diterapkan migran di daerah tujuan.

2. Menganalisis prioritas adaptasi migran di daerah tujuan.

3. Menganalisis peran jaringan sosial dalam proses adaptasi migran di daerah tujuan.

\section{Kegunaan Penelitian}

Penelitian ini diharapkan dapat memberikan pengantar atau sebagai pengenalan lebih lanjut mengenai bentuk- bentuk jaringan sosial dan strategi adaptasi yang diterapkan tenaga kerja migran di daerah tujuan. Selain itu penelitian ini diharapkan dapat memberikan manfaat bagi peneliti sebagai sarana untuk memahami permasalahan migrasi, khususnya migrasi tenaga kerja, sekaligus untuk mencari penguatan teori yang telah ada. Melalui penelitian ini, terdapat juga beberapa hal yang ingin penulis sumbangkan pada berbagai pihak, yaitu:

1. Akademisi, di mana penelitian ini diharapkan dapat menjadi referensi bagi peneliti yang ingin mengkaji permasalahan migrasi, khususnya yang berkaitan dengan jaringan sosial dan strategi adaptasi tenaga kerja migran, serta untuk meningkatkan kemampuan peneliti dalam menerapkan berbagai konsep migrasi.

2. Masyarakat, di mana penelitian ini diharapkan dapat berdampak positif bagi masyarakat, khususnya tenaga kerja migran, untuk menambah pengetahuan tentang kajian permasalahan migrasi, pentingnya peran jaringan sosial dan strategi yang dapat diterapkan untuk dapat bertahan hidup dengan lebih baik.

3. Pemerintah, di mana penelitian ini diharapkan dapat memberikan masukan atau dijadikan bahan pertimbangan bagi para penentu kebijakan (pemerintah) dalam merencanakan, mengambil keputusan dan membuat kebijakan tentang migrasi, khususnya migrasi tenaga kerja.

\section{PENDEKATAN TEORITIS}

\section{Migrasi}

Rusli (1996) menyatakan bahwa mobilitas penduduk terbagi menjadi dua bentuk, yaitu yang bersifat permanen dan yang bersifat non permanen. Mobilitas penduduk permanen dikenal dengan istilah migrasi, yaitu perpindahan tempat tinggal secara permanen atau relatif permanen (untuk jangka waktu minimal tertentu) dengan menempuh jarak minimal tertentu, atau pindah dari satu unit geografis ke unit geografis lainnya. Sementara itu, mobilitas penduduk non permanen terbagi menjadi sirkulasi dan komutasi. Sirkulasi adalah gerak "berselang" antara tempat tinggal dan tempat tujuan baik untuk bekerja maupun untuk tujuan lainnya, sedangkan komutasi adalah gerak berulang hampir setiap hari (gerak penduduk harian) antara tempat tinggal dan tempat tujuan (Rusli 1996).

Ravenstein, sebagaimana dikutip oleh Lee (1984), mengemukakan tujuh teori yang merupakan penggenerasian dari teori migrasi, yaitu :

1. Migrasi dan jarak, di mana banyak migran memilih bermigrasi pada jarak yang dekat dibandingkan dengan jarak yang jauh dan migrasi lebih tertuju ke pusat-pusat perdagangan dan industri yang penting.

2. Migrasi bertahap, artinya adanya arus migrasi yang terarah dan adanya migrasi dari desa-kota kecil-kota besar.

3. Arus dan arus balik, artinya setiap arus migrasi utama menimbulkan arus balik penggantiannya.

4. Adanya perbedaan antara desa dan kota akan mengakibatkan timbulnya migrasi.

5. Wanita melakukan migrasi pada jarak yang dekat dibandingkan pria.

6. Teknologi dan migrasi, artinya bahwa teknologi menyebabkan migrasi meningkat.

7. Motif ekonomi merupakan dorongan utama orang melakukan migrasi.

Lee (1984) menyatakan bahwa terdapat empat faktor yang menyebabkan seseorang mengambil keputusan untuk melakukan migrasi, yaitu faktor-faktor yang terdapat di daerah asal, faktor-faktor yang terdapat di daerah tujuan, rintangan-rintangan yang menghambat dan faktor-faktor pribadi.

Faktor yang menyebabkan seseorang mengambil keputusan untuk melakukan migrasi atau faktor yang 
memotivasi seseorang untuk melakukan migrasi dapat disederhanakan menjadi dua faktor, yaitu faktor pendorong dari daerah asal dan faktor penarik dari daerah tujuan. Teori ini dikenal dengan istilah Pull-Push Theory di mana di setiap daerah banyak faktor yang mempengaruhi seseorang untuk menetap atau menarik orang untuk pindah ke tempat itu dan ada pula faktor-faktor lain yang memaksa mereka meninggalkan daerah tersebut. Untuk daerah asal, faktor negatif menjadi daya dorong terhadap seseorang untuk pergi meninggalkan daerah tersebut dan faktor positif berfungsi sebagai penghambat seseorang untuk pindah ke daerah lain. Di lain pihak, faktor positif di daerah tujuan menjadi daya tarik terhadap seseorang untuk datang ke daerah tersebut dan faktor negatif akan menghambat masuknya seseorang ke daerah tersebut.

\section{Adaptasi}

Menurut Avin (1994), adaptasi merupakan tingkah laku yang melibatkan perencanaan agar dapat mengantisipasi suatu peristiwa di masa yang akan datang. Dalam konteks migrasi, proses adaptasi yang dilakukan migran dibedakan berdasarkan jenisnya, yaitu adaptasi sosial dan adaptasi ekonomi (Frank, 2004 dan Nainggolan, 2001).

Adaptasi sosial adalah proses penyesuaian diri di lingkungan sosial yang salah satunya dilakukan dengan cara membentuk jaringan sosial untuk memberi dukungan psikologi dan membantu migran agar dapat survive di lingkungan baru, sementara adaptasi ekonomi adalah penyesuaian diri dalam segi ekonomi yang dilakukan dalam rangka memenuhi kebutuhan dan mencapai kesuksesan secara finansial yang umumnya dilakukan dengan cara bergabung dalam kelompok atau organisasi kecil seperti kelompok arisan atau koperasi yang dapat membantu mengelola keuangan migran (Yusuf, 2006) serta menerapkan pola nafkah ganda dan memaksimalkan jam kerja di atas jam kerja normal untuk menambah penghasilan (Frank, 2004).

Adaptasi juga dapat dibagi menjadi dua tahapan, yaitu pada masa awal migrasi dan pada masa perkembangan (Yusuf, 2006). Pada masa awal migrasi, kerentanan migran terhadap tekanan-tekanan yang terdapat di daerah tujuan mengakibatkan kehidupan migran tidak stabil. Oleh sebab itu adaptasi dilakukan agar migran dapat bertahan dan menyesuaikan diri terhadap tekanan-tekanan di lingkungan baru tersebut. Adaptasi ini dilakukan migran dengan cara menumpang di tempat tinggal migran terdahulu untuk tujuan ekonomi, sosial dan informasi, atau dengan cara bertempat tinggal di lingkungan yang dekat dengan kerabat dan bergabung dalam paguyuban.

Hal ini dilakukan agar migran dapat dengan mudah meminta bantuan kerabat atau temannya jika migran tersebut mengalami kesulitan dan sebagai strategi berhemat. Selain itu, strategi bergabung dalam paguyuban berguna untuk memperoleh modal dan membantu mengarahkan dan mencarikan pekerjaan bagi migran.

Sementara itu, pada masa perkembangan, adaptasi dilakukan untuk menyesuaikan diri dengan lingkungan agar memperoleh kesuksesan di daerah tujuan karena umumnya migran bermigrasi dengan tujuan memperoleh kehidupan yang lebih baik daripada kehidupan sebelumnya di daerah asal (Yusuf, 2006). Adaptasi ini dilakukan dengan mengembangkan keterampilan dalam pekerjaan agar memperoleh pendapatan yang lebih besar, menerapkan pola nafkah ganda dan mengembangkan jaringan sosial.

\section{Jaringan Sosial}

Jaringan sosial didefinisikan sebagai seperangkat hubungan-hubungan khusus atau spesifik yang terbentuk di antara sekelompok orang, di mana karakteristik hubungan-hubungan tersebut dapat digunakan untuk menginterpretasikan motif-motif perilaku sosial dari orang-orang yang terlibat di dalamnya (Mitchell 1969, dalam Haryono tt). Dalam hubungannya dengan migrasi, jaringan sosial dibentuk antara migran terdahulu dengan migran baru dan antara migran dengan masyarakat setempat (Fadhilah, 2007). Umumnya migran terdahulu merupakan keluarga, kerabat, tetangga dan teman sedaerah asal migran baru.

Awal pembentukan jaringan sosial adalah sebelum bermigrasi (Tarigan, 2004). Sebelum bermigrasi terdapat ikatan, baik antar personal langsung migran, atau antar keluarga migran yang sudah terjalin di desa, bahkan banyak migran terdahulu yang menjalin kontak dengan calon migran sebelum calon migran memutuskan bermigrasi. Adanya jaringan sosial merupakan salah satu faktor yang memengaruhi motivasi seseorang untuk bermigrasi. Ajakan kerabat, keluarga, tetangga atau teman sedaerah asal dan keberadaan mereka di daerah tujuan menjadi faktor penarik bagi migran baru (Irfan, 2007).

Selain sebagai faktor penarik migrasi, jaringan sosial juga berfungsi sebagai strategi adaptasi migran di daerah tujuan yang dapat membantu migran agar dapat survive di lingkungan baru (Haryono tt). Migran terdahulu sebagai jaringan sosial pertama migran baru berperan dalam menyediakan tempat tinggal sementara, mencukupi kebutuhan makan dan membantu mencarikan pekerjaan untuk migran baru (Fierda, 2007). Tempat tinggal yang dekat dengan migran terdahulu berguna agar jaringan sosial di antara sesama migran sedaerah asal berkembang dan terpelihara.

Dalam kaitannya dengan pekerjaan, umumnya migran baru akan menggeluti bidang yang tidak jauh berbeda dengan migran terdahulu yang mengajaknya bermigrasi, sebagaimana digambarkan Yusuf (2006). Kondisi ini terjadi karena sumber informasi utama bagi migran baru, khususnya mengenai pekerjaan, lebih banyak didapat dari keluarga atau kerabat karena hubungan kekerabatan yang dekat menyebabkan aliran informasi lebih mudah, cepat dan tanpa biaya (Frank, 2004). Proses mencari pekerjaan pun berkisar antar relasi migran (Tarigan, 2004). Hal ini menjelaskan mengapa lapangan pekerjaan tertentu di suatu kota atau daerah sering didominasi oleh migran yang berasal dari desa atau daerah tertentu.

Secara rinci, fungsi jaringan sosial dibedakan menjadi tiga kategori (Irfan, 2007), antara lain:

a. Fungsi ekonomi, yaitu untuk mendapatkan bantuan modal, berupa uang dan barang, yang digunakan untuk memulai usaha atau untuk mendapat pekerjaan. Kerabat yang telah berhasil akan membantu migran baru untuk memperoleh pekerjaan karena rasa tanggung jawab untuk membantu kerabatnya.

b. Fungsi sosial, yaitu untuk jaminan sosial dan sosialisasi 
kerja. Jaminan sosial yang dimaksud adalah tersedianya tempat tinggal dan makanan ketika migran baru bermigrasi serta perlindungan dan berbagai bantuan yang diberikan migran terdahulu, sedangkan sosialisasi kerja dilakukan dengan magang (dalam kasus tertentu) untuk memperoleh pengalaman dan pengetahuan tentang seluk beluk pekerjaan yang akan digeluti migran.

c. Fungsi informasi, yaitu untuk mengalirkan informasi tentang pekerjaan. Informasi tersebut antara lain berupa informasi tentang peluang kerja dan strategi. hal ini agar pekerjaan migran berhasil.

\section{Kerangka Berpikir}

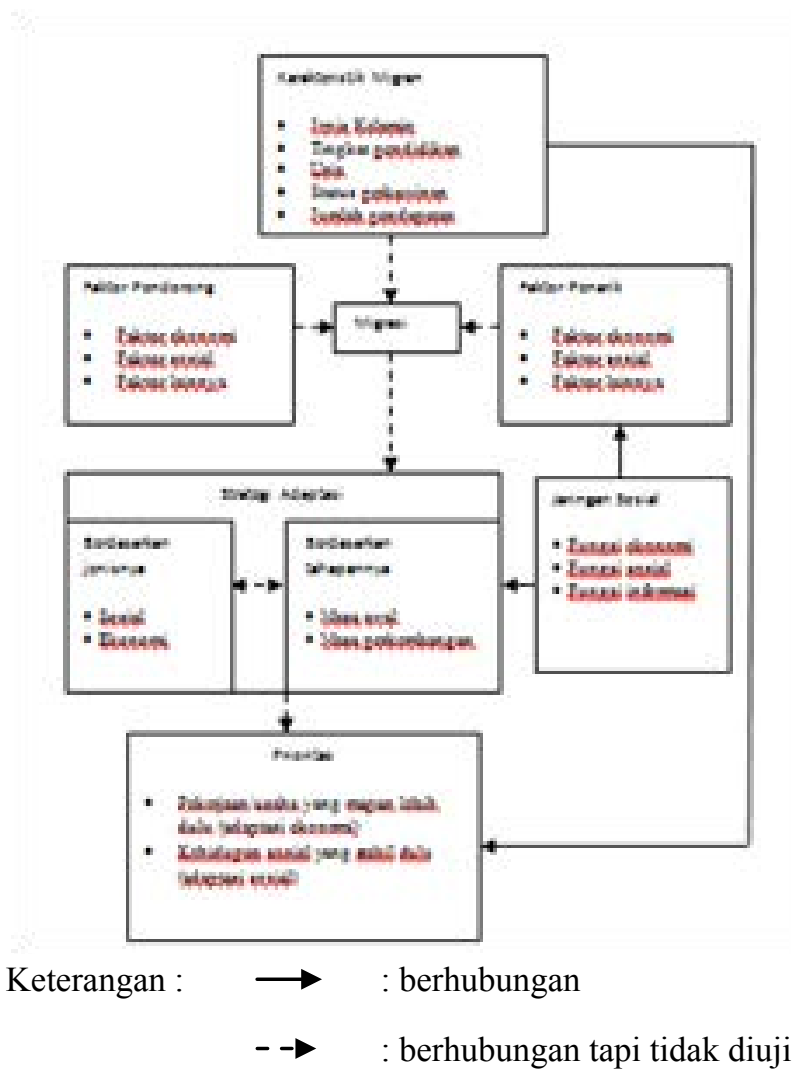

Gambar 1. Kerangka Berpikir

Dalam bermigrasi, selain karakteristik migran berupa usia, pendidikan, status perkawinan dan pendapatan, faktor-faktor yang ada di dareah asal dan daerah tujuan juga memengaruhi keputusan migran untuk bermigrasi. Faktor- faktor yang ada di daerah asal menjadi faktor pendorong, sedangkan faktor-faktor yang ada di daerah tujuan merupakan faktor penarik. Faktor- faktor tersebut terdiri atas faktor ekonomi, faktor sosial dan faktor lainnya. Keberadaan migran terdahulu sebagai jaringan sosial migran baru juga memengaruhi keputusan bermigrasi, di mana keberadaan jaringan sosial ini dikategorikan sebagai faktor penarik migrasi.

Setelah bermigrasi, migran baru menerapkan strategi adaptasi agar mampu bertahan menghadapi tekanantekanan di daerah baru. Dalam proses adaptasinya, migran baru menerapkan strategi adaptasi sosial dan strategi adaptasi ekonomi. Adaptasi juga dilakukan dalam dua tahap, yaitu pada masa awal migrasi dan pada masa perkembangan. Dalam menerapkan strategi adaptasinya, umumnya migran menetapkan adaptasi mana yang lebih diutamakan atau dengan kata lain migran membuat prioritas adaptasi. Prioritas adaptasi migran dibedakan menjadi dua, yaitu adaptasi sosial yang ditujukan untuk mencapai kehidupan sosial yang stabil lebih dahulu dan adaptasi ekonomi yang ditujukan untuk mencapai kemapanan pekerjaan lebih dulu. Karakteristik migran selain memengaruhi keputusan bermigrasi juga diduga memengaruhi prioritas adaptasi migran. Migran terdahulu sebagai jaringan sosial migran di daerah tujuan diduga memengaruhi proses adaptasi tersebut.

\section{Hipotesis}

Sesuai dengan permasalahan yang dikaji, maka hipotesis yang disoroti adalah:

1. Terdapat hubungan antara karakteristik migran dengan prioritas adaptasi yang diterapkan migran.

2. Terdapat hubungan antara jaringan sosial dengan proses adaptasi migran.

\section{PENDEKATAN LAPANGAN}

\section{Lokasi dan Waktu Penelitian}

Penelitian ini dilaksanakan di Desa Jayamukti, Kecamatan Cikarang Pusat, Kabupaten Bekasi, Provinsi Jawa Barat. Lokasi ini dipilih karena merupakan salah satu pusat industri yang menarik tenaga kerja dari berbagai tempat, baik dari Jawa maupun luar Jawa. Pemilihan lokasi penelitian dilakukan secara sengaja (purposive) sesuai dengan kebutuhan penelitian. Studi lapangan dilaksanakan pada bulan Oktober 2011.

\section{Jenis Data dan Metode Pengumpulan Data}

Penelitian ini merupakan penelitian survei dengan metode explanatory atau confirmatory research. Penelitian explanatory merupakan penelitian yang menjelaskan hubungan kausal antar variabel-variabel penelitian dan menguji hipotesa yang telah dirumuskan sebelumnya (Singarimbun dan Effendi, 2008). Jenis data yang digunakan dalam penelitian ini adalah data primer dan sekunder. Data primer didapat melalui penilitian langsung dengan menggunakan kuesioner dan wawancara bebas, sementara data sekunder didapat dari kantor Desa Jayamukti. Metode yang dipakai dalam penelitian ini adalah wawancara, observasi dan dokumentasi. Pendekatan yang dilakukan dalam penelitian ini adalah pendekatan kuantitatif dengan didukung oleh data kualitatif untuk memperkaya data dan memahami fenomena sosial.

\section{Teknik Pengambilan Sampel}

Populasi sampling dalam penelitian ini adalah tenaga kerja migran yang ada di Desa Jayamukti, Kecamatan Cikarang Pusat, Kabupaten Bekasi, Provinsi Jawa Barat, sedangkan populasi sasaran penelitian ini adalah tenaga kerja migran yang berasal dari Lampung. Unit analisis dalam penelitian ini adalah individu. Kerangka sampel disusun menggunakan metode "snowball" karena data penduduk untuk menyusun kerangka sampel tidak tersedia. Metode tersebut dilakukan dengan menanyakan keberadaan migran asal Lampung di Desa tersebut kepada seorang informan. Setelah didapat satu alamat seorang 
migran asal Lampung sebagai responden, penulis kemudian mendatangi dan mewawancara responden tersebut. Di akhir wawancara, penulis menanyakan ada atau tidaknya migran asal Lampung lain di desa tersebut kepada responden. Berdasarkan informasi dari responden tersebut, penulis mendatangi migran lain yang memenuhi kriteria sebagai responden dan mengulangi prosedur yang sama hingga tidak ada lagi nama baru yang disebutkan responden.

Teknik pengambilan sampel yang digunakan dalam penelitian ini adalah sensus karena berdasarkan kerangka sampel yang telah disusun didapat jumlah populasi sasaran di Desa Jayamukti hanya 38 orang sehingga seluruh anggota populasi sasaran diambil sebagai responden, kecuali dua orang di mana kedua orang tersebut menolak untuk diwawancara. Jumlah responden sebanyak 36 orang dirasa cukup untuk memenuhi reliabilitas dan validitas data.

\section{Teknik Pengolahan dan Analisis Data}

Data kuantitatif yang diperoleh melalui kuesioner kemudian diolah dengan cara mengkode data, kemudian dianalisis dengan menggunakan komputer. Dalam hal ini program komputer yang digunakan adalah Microsoft Excel dan SPSS. Microsoft Excel digunakan untuk memasukkan data yang telah dikode, sementara SPSS digunakan untuk merekam data yang bersifat ordinal dan nominal, membuat tabel frekuensi dan membuat tabulasi silang. Tabulasi silang digunakan untuk menggambarkan hubungan antara dua variabel dan mempermudah dalam membaca serta memahami data. Data tersebut kemudian diinterpretasikan dan ditarik kesimpulan berdasarkan hipotesis yang ada Selain analisis data kuantitatif, dilakukan pula analisis data kualitatif sebagai pendukung untuk mempertajam hasil penelitian.

\section{GAMBARAN UMUM LOKASI PENELITIAN}

\section{Kondisi Geografis}

Cikarang merupakan salah satu pusat industri di Indonesia. Lokasi Cikarang yang dekat dengan Ibukota Jakarta memberi nilai tersendiri bagi perkembangan kota ini. Keberadaan industri-industri besar di Cikarang dan ditunjang oleh kedekatan wilayahnya dengan Jakarta dan kelancaran transportasinya membuat wilayah ini menjadi salah satu tempat tujuan migrasi terbesar di Indonesia.

Desa Jayamukti merupakan bagian dari wilayah Cikarang Pusat. Selain dekat dengan Ibukota Cikarang Pusat, yaitu sejauh $4 \mathrm{~km}$, Desa Jayamukti juga dekat dengan pusat industri Jababeka dan Delta Mas. Desa ini terdiri atas tujuh dusun/RW, yaitu Dusun I Tunggul Danas, Dusun II Rawa Sentul, Dusun III KND Gereng, RW 07 Cikarang Baru, RW 08 Cikarang Baru, RW 09 Cikarang Baru dan RW 10 Cikarang Baru. Secara umum desa ini berbatasan dengan:

$\begin{array}{lll}\text { a. } & \text { Sebelah utara } & \text { : Desa Sertajaya } \\ \text { b. } & \text { Sebelah selatan } & \text { : Desa Sukamahi } \\ \text { c. } & \text { Sebelah barat } & \text { : Desa Pasirsari } \\ \text { d. } & \text { Sebelah timur } & \text { : Desa Mekartimur }\end{array}$

Berdasarkan Pofil Desa Jayamukti tahun 2008 diketahui bahwa secara geografis Desa Jayamukti memiliki bentang lahan berupa dataran dengan luas 518,5 ha. Dari jumlah tersebut 77 ha di antaranya dimanfaatkan untuk pemukiman dan 215 ha dimanfaatkan untuk pertanian. Desa ini berada pada ketinggian $1 \mathrm{~km}$ di atas permukaan laut dengan curah hujan rata-rata per tahun sebesar $300 \mathrm{~mm}$ dan keadaan suhu rata-rata sebesar 280 C -310 C. Kondisi tersebut menyebabkan lahan di desa ini dinilai kurang subur sehingga tidak cocok untuk dimanfaatkan sebagai lahan pertanian.

\section{Kondisi Ekonomi dan Sosial}

Jumlah penduduk Desa Jayamukti adalah sebesar 16.648 jiwa yang terdiri atas 4.976 kepala keluarga (Pemerintah Desa Jayamukti 2008). Dengan membandingkan jumlah penduduk dan luas lahan, maka didapat kepadatan penduduk Desa Jayamukti sebesar 1200 jiwa $/ \mathrm{km}$. Dari keseluruhan jumlah penduduk, sebanyak 1.762 jiwa merupakan penduduk miskin atau memiliki tingkat ekonomi yang rendah.

Lapangan pekerjaan yang tersedia di Desa Jayamukti terdiri atas subsektor pertanian, peternakan, industri kecil/ kerajinan, industri sedang/besar dan jasa/ perdagangan. Sektor industri, khususnya subsektor industri sedang/ besar, menjadi matapencaharian utama penduduk Desa Jayamukti. Sebanyak 9.831 orang bekerja pada subsektor ini dan 9.782 orang di antaranya bekerja sebagai buruh pabrik. Kondisi industri di Cikarang berkembang pesat dengan masuknya perusahaan-perusahaan asing yang kemudian membentuk lima kawasan industri besar di Cikarang, antara lain Jababeka, Delta Silicon, Ejip, Hyundai dan Delta Mas. Sementara itu, berdasarkan pendidikannya, penduduk Desa Jayamukti berada pada tingkat pendidikan sedang, di mana 6.723 penduduk berpendidikan SMA dan 2.383 berpendidikan SMP.

Secara umum, pola pemukiman penduduk Desa Jayamukti terdiri atas kompleks perumahan dan perkampungan. Masyarakat pendatang (migran) tinggal di dalam kompleks, sementara penduduk asli tinggal di perkampungan. Terpisahnya pemukiman migran dan penduduk asli desa tersebut menyebabkan interaksi antara migran dengan penduduk asli menjadi rendah. Di dalam kompleks perumahan, tempat tinggal migran tidak dibedakan berdasarkan daerah asal migran. Semua migran dari berbagai daerah tinggal bersama-sama di kompleks tersebut. Meskipun begitu, terdapat juga migran yang tinggal di luar kompleks. Hal ini disebabkan biaya untuk tinggal di kompleks tersebut relatif mahal untuk sebagian migran. Dari hasil wawancara dengan pemerintah diketahui bahwa tempat tinggal penduduk, yaitu di dalam dan di luar kompleks (termasuk di perkampungan), menunjukkan perbedaan status ekonomi di mana penduduk yang tinggal di dalam kompleks memiliki tingkat ekonomi yang lebih tinggi dibandingkan dengan penduduk yang tinggal di luar kompleks.

\section{Kondisi Kependudukan}

Penduduk Desa Jayamukti terdiri atas penduduk lokal dan migran. Mobilitas penduduk di desa ini cukup tinggi di mana setiap tahun terdapat migran yang datang ke desa ini dan terdapat juga penduduk yang pindah dari desa ini. Berdasarkan Laporan Data Penduduk Desa Jayamukti Bulan Januari Tahun 2011 terdapat 26 orang yang datang dan 18 orang yang meninggalkan wilayah tersebut. Migran yang datang ke daerah ini tidak hanya berasal dari pulau 
Jawa melainkan dari luar Jawa.

Lokasi Desa Jayamukti yang strategis menyebabkan desa ini dijadikan sebagai lokasi pemukiman, baik bagi masyarakat setempat maupun bagi migran yang bermigrasi untuk mencari pekerjaan di Cikarang. Penduduk Desa Jayamukti didominasi oleh migran, yaitu sebanyak 75\% dari total populasi yang ada di desa tersebut. Hal ini disebabkan oleh perkembangan industri di Cikarang yang berkembang pesat sehingga menarik banyak migran untuk datang.

Kebanyakan migran tidak memiliki KTP setempat dan masih menggunakan KTP dari daerah asalnya. Untuk melamar pekerjaan, migran hanya mengguanakan surat keterangan domisili sementara dari RT setempat. Ketika pertama kali datang ke Desa Jayamukti migran mendapat ijin domisili selama tiga bulan dan bisa diperpanjang lagi hingga enam bulan berikutnya, namun setelah sembilan bulan tinggal di desa tersebut jarang sekali migran yang membuat KTP sebagai warga desa tersebut. Tidak adanya ikatan resmi dengan Desa Jayamukti mengakibatkan banyak migran yang tidak melapor ke pemerintah setempat ketika akan bermigrasi ke daerah lain.

Sebagian besar migran datang ke Desa Jayamukti untuk mencari pekerjaan di Cikarang. Mereka tetap tinggal di desa ini hingga mendapat pekerjaan atau pindah ke daerah lain yang dianggap memiliki peluang kerja yang lebih besar. Hanya sedikit sekali migran yang belum mendapatkan pekerjaan yang kembali ke daerah asalnya. Peluang kerja dibidang industri lebih terbuka bagi para migran dibandingkan dengan penduduk asli Desa Jayamukti. Selain karena tingkat pendidikan migran lebih tinggi dibandingkan pendidikan penduduk asli, hal ini juga disebabkan oleh adanya relasi migran dengan jaringan sosialnya yang memudahkan migran dalam mendapatkan pekerjaan. Meskipun fenomena ini berpotensi menimbulkan konflik, namun hingga saat penelitian dilaksanakan penduduk asli dan para migran hidup dengan damai dan tidak terjadi konflik sosial.

\section{HASIL PENELITIAN}

\section{Karakteristik Migran}

\section{Jenis Kelamin}

Secara umum laki-laki lebih mudah melakukan migrasi dibandingkan perempuan karena kondisi perempuan yang sarat dengan nilai-nilai budaya, seperti kewajiban mengurus rumah tangga dan kewajiban mengikuti suami, menghambat perempuan untuk melakukan mobilisasi. Meskipun begitu, banyaknya kebutuhan hidup yang harus dipenuhi membuat perempuan juga terdorong untuk melakukan migrasi untuk mencari kehidupan yang lebih baik. Berdasarkan penelitian, diketahui bahwa jumlah migran perempuan lebih banyak daripada jumlah migran laki-laki. Hal ini disebabkan umumnya industri yang ada di Cikarang lebih membutuhkan pekerja perempuan karena pekerjaan pada industri tersebut membutuhkan ketelitian yang tinggi dan pekerja perempuan dianggap lebih mudah dikoordinasi dibandingkan dengan pekerja lakilaki. Besarnya peluang kerja bagi perempuan ini menarik migran perempuan untuk bermigrasi ke Cikarang.

\section{Usia}

Usia menjadi faktor penting dalam pengambilan keputusan untuk bermigrasi. Dalam usia yang masih sangat muda seseorang biasanya masih bergantung kepada orang tua atau wali sehingga umumnya mereka canderung tidak melakukan migrasi atau bermigrasi karena ikut orang tua atau wali. Begitu pula dengan orang yang sudah lanjut usia. Umumnya seseorang sudah tidak aktif lagi melakukan mobilisasi dalam usia yang telah lanjut. Hal ini sesuai dengan teori Rusli (1996) yang menyatakan bahwa migrasi dilakukan oleh individu pada usia produktif.

Dalam penelitian ini usia dilihat dalam dua kondisi, yaitu usia saat pertama kali meninggalkan kampung halaman dan saat penelitian dilaksanakan. Mengikuti cara Pane (2004), penulis membagi usia saat pertama kali meninggalkan kampung halaman ke dalam tiga kategori, yaitu kurang dari 15 tahun, 15-24 tahun dan lebih dari 24 tahun, sementara usia saat penelitian dilaksanakan dibedakan menjadi kurang dari 24 tahun, 24-35 tahun dan lebih dari 35 tahun. Tidak banyak migran yang meninggalkan kampung halamannya dalam usia kurang dari 15 tahun. Selain karena peran orang tua masih sangat kuat, hal ini juga disebabkan karena usia kurang dari 15 tahun adalah usia sekolah sehingga mengikat mereka untuk tidak melakukan migrasi. Sebagian besar migran mulai bermigrasi pada rentang usia 15-24 tahun. Usia tersebut adalah usia di mana seseorang menyelesaikan sekolah tingkat SMP dan SMA sehingga mereka tidak lagi terikat dengan kepentingan sekolah. Pada usia ini juga, khususnya antara usia 18-24 tahun, seseorang sudah mulai dapat mengambil keputusan sendiri tanpa terlalu melibatkan orang tua. Sementara itu, saat penelitian dilaksanakan usia migran yang paling dominan berada pada rentang usia 24-35 tahun.

\section{Pendidikan}

Pendidikan dan ketenagakerjaan merupakan dua hal yang saling berhubungan. Untuk memasuki sebuah lapangan pekerjaan dibutuhkan pengetahuan dan keterampilan yang didapat baik melalui pendidikan formal maupun pendidikan informal. Oleh sebab itu, pendidikan merupakan faktor penting yang harus dikaji untuk memahami masalah ketenagakerjaan. Ketika meninggalkan kampung halaman, sebagian besar migran asal Lampung telah menyelesaikan sekolah tinggkat SMP dan SMA. Oleh sebab itu, pendidikan saat migran meninggalkan kampung halamannya didominasi oleh tingkat pendidikan SMA dan urutan kedua yang terbesar ditempati oleh tingkat pendidikan SMP.

Di daerah tujuan migrasi, sebagian kecil migran melanjutkan pendidikan. Hal ini menyebabkan kondisi pendidikan saat migran meninggalkan kampung halaman sedikit berbeda dengan kondisi pendidikan migran saat penelitian dilaksanakan. Saatpenelitian dilaksanakanjumlah migran yang berpendidikan SMP berkurang dibandingkan dengan saat meninggalkan kampung halaman, sementara jumlah migran yang berpendidikan SMA tetap sama. Di lain pihak, jumlah migran yang berpendidikan diploma dan sarjana saat penelitian dilaksanakan bertambah. Pendidikan migran yang didominasi pada tingkat SMA mewakili fakta bahwa sebagian besar penduduk Indonesia umumnya hanya menempuh pendidikan hingga tingkat SMA. 


\section{Status Perkawinan}

Status perkawinan yang dahulu merupakan faktor penghambat migrasi kini tidak lagi menjadi hambatan bagi seseorang untuk melakukan migrasi. Dengan semakin berkembangnya jaman, di mana teknologi dan transportasi mengalami kemajuan pesat, faktor pernikahan tidak lagi mengikat seseorang untuk tinggal di suatu wilayah. Dalam penelitian ini didapat data bahwa semua migran berstatus single saat meninggalkan kampung halaman. Meskipun ikatan pernikahan tidak menjadi hambatan dalam bermigrasi, namun kondisi migran yang tidak terikat perkawinan lebih mempermudah migran dalam melakukan migrasi. Sementara itu, pada saat penelitian dilaksanakan didapat data bahwa sebagian besar migran sudah menikah.

\section{Pendapatan}

Alasan utama seseorang bermigrasi adalah untuk mencari kehidupan yang lebih baik. Salah satu cara untuk mendapat kehidupan yang lebih baik adalah dengan mencari sumber pendapatan yang lebih baik pula agar dapat memenuhi kebutuhan hidup. Berdasarkan hasil penelitian diketahui bahwa hanya ada dua orang migran yang memiliki pekerjaan sebelum bermigrasi. Seseorang diantaranya bekerja sebagai petani di kampung halamannya dengan penghasilan Rp 500.000/bulan, sedangkan seseorang lainnya bekerja sebagai pencacah/pengawas BPS dengan pendapatan yang tidak dapat mencukupi kebutuhan hidupnya. Setelah bermigrasi dan mendapat pekerjaan, migran memiliki pendapatan yang lebih baik dibandingkan saat belum bermigrasi.

Tabel 1. Jumlah Migran Menurut Pekerjaan dan Pendapatan Saat Penelitian Dilaksanakan, Desa Jayamukti, 2011

\begin{tabular}{|c|c|c|c|c|c|c|c|c|}
\hline \multirow{3}{*}{ Pekerjaan } & \multicolumn{8}{|c|}{ Pendapatan } \\
\hline & \multicolumn{2}{|c|}{$<1.5$ juta } & \multicolumn{2}{|c|}{$1.5-4$ juta } & \multicolumn{2}{|c|}{$>4$ juta } & \multicolumn{2}{|c|}{ Jumlah } \\
\hline & $\mathrm{n}$ & $\%$ & $\mathrm{n}$ & $\%$ & $\mathrm{n}$ & $\%$ & $\mathrm{n}$ & $\%$ \\
\hline $\begin{array}{l}\mathrm{B} \underset{\text { pabrik }}{\mathrm{u}} \mathrm{r} \\
\mathrm{u} \quad \mathrm{h}\end{array}$ & 3 & 17.6 & 12 & 70.6 & 2 & 11.8 & 17 & 100 \\
\hline Pedagang & 1 & 20 & 1 & 20 & 3 & 60 & 5 & 100 \\
\hline Wiraswasta & 1 & 20 & 0 & 0 & 4 & 80 & 5 & 100 \\
\hline $\begin{array}{l}\text { Pemilik kon- } \\
\text { ter HP }\end{array}$ & 1 & 50 & 1 & 50 & 0 & 0 & 2 & 100 \\
\hline $\begin{array}{l}\mathrm{P} \text { e } \mathrm{m} \mathrm{i} 1 \mathrm{i} \mathrm{k} \\
\text { warung nasi }\end{array}$ & 1 & 100 & 0 & 0 & 0 & 0 & 1 & 100 \\
\hline $\begin{array}{l}\text { Pemilik sa- } \\
\text { lon }\end{array}$ & 1 & 100 & 0 & 0 & 0 & 0 & 1 & 100 \\
\hline Satpam & 0 & 0 & 0 & 0 & 1 & 100 & 1 & 100 \\
\hline Jurnalis & 0 & 0 & 2 & 100 & 0 & 0 & 2 & 100 \\
\hline $\begin{array}{l}\text { Guru (swaa- } \\
\text { ta) }\end{array}$ & 1 & 100 & 0 & 0 & 1 & 100 & 1 & 100 \\
\hline Jumlah & 9 & 25 & 16 & 44.4 & 11 & 30.6 & 36 & 100 \\
\hline
\end{tabular}

Pendapatan yang diperoleh migran selama tinggal di Cikarang cukup beragam. Pendapatan migran yang paling kecil adalah sebesar Rp 500.000/bulan sementara pendapatan migran yang paling besar adalah Rp 30.000.000/ bulan. Selain dipengaruhi oleh jenis pekerjaan, jumlah pendapatan migran juga dipengaruhi oleh jumlah pekerjaan dan jam kerja migran. Dalam penelitian ini, pendapatan migran dikelompokkan menjadi tiga kategori, yaitu kurang dari $R p$ 1.500.000, Rp 1.500.000 - Rp 4.000.000 dan lebih dari $\mathrm{Rp}$ 4.000.000. Pendapatan migran didominasi pada rentang $\mathrm{Rp} 1.500 .000$ - Rp 4.000.000 dan sebagian besar migran pada rentang pendapatan ini bekerja sebagai buruh pabrik. Terdapat dua orang migran yang memiliki pendapatan $\mathrm{Rp} 500.000$. Kedua migran tersebut adalah migran yang bekerja sebagai pedagang atau penjaga toko milik tetangga sedaerah asalnya dan migran yang bekerja sebagai penjual nasi. Sebelum bermigrasi, migran yang bekerja sebagai penjaga toko telah memiliki pekerjaan, yaitu sebagai petani dengan penghasilan rata-rata sebesar Rp 500.000. Meskipun pendapatan yang diperoleh di daerah tujuan sama dengan pendapatan yang diperoleh sebelum bermigrasi, namun pekerjaan yang digelutinya saat ini dinilai lebih baik dan lebih mudah untuk dikerjakan. Sementara itu, migran yang memiliki penghasilan paling besar adalah adalah migran yang bekerja sebagai wiraswasta dan pedagang. Migran ini memiliki pekerjaan ganda dengan usaha yang berkembang pesat dan jaringan sosial yang luas.

\section{Migrasi}

Dalam penelitian ini, tahun migrasi dibedakan atas dua bentuk, yaitu tahun saat migran pertama kali meninggalkan kampung halaman dan tahun saat migran pertama kali bermigrasi ke Cikarang. Sebagian migran meninggalkan kampung halamannya lebih dari sepuluh tahun yang lalu, namun ada pula beberapa migran yang baru bermigrasi setahun yang lalu. Data mengenai tahun migran meninggalkan kampung halaman dan tahun saat migran bermigrasi ke Cikarang dapat dilihat dalam gambar berikut.

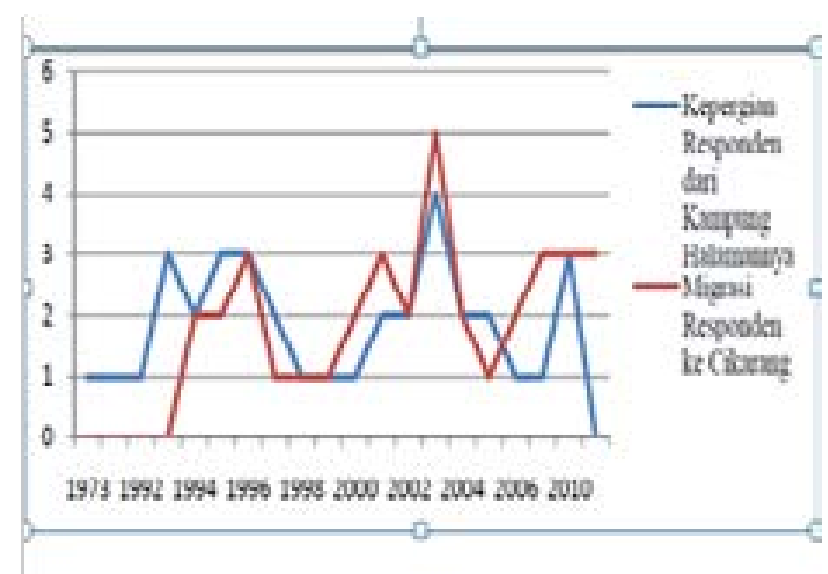

Gambar 2. Tahun Migrasi Migran

Dari gambar tersebut terlihat bahwa sebelum tahun 1990 hanya sedikit migran yang meninggalkan Lampung. Angka ini terus mengalami fluktuasi dan mencapai puncak pada tahun 2003, namun sejak tahun 2004 hingga tahun 2007 jumlah migran yang meninggalkan Lampung semakin menurun, bahkan tidak ada migran yang meninggalkan Lampung pada tahun 2008 dan 2009. Berdasarkan gambar tersebut juga diketahui bahwa migran mulai bermigrasi ke Cikarang sejak tahun 1994 karena Cikarang mulai berkembang pesat pada awal dekade 1990-an. Migrasi ke Cikarang paling banyak terjadi pada tahun 2003, bertepatan dengan tahun di mana Kabupaten Bekasi, termasuk Cikarang, menjadi penyumbang terbesar bagi pertumbuhan ekonomi Indonesia. 


\section{Daerah Tujuan Migrasi}

Setelah meninggalkan Lampung, daerah tujuan migrasi migran yang pertama di dominasi oleh Jakarta. Hal ini disebabkan citra Jakarta sebagai ibu kota dan pusat perekonomian menarik migran untuk datang ke daerah tersebut untuk mencari pekerjaan. Tempat kedua yang menjadi daerah yang paling banyak menarik migran ketika meninggalkan Lampung adalah Cikarang. Selain Jakarta dan Cikarang, daerah industri lain seperti Bogor, Tangerang dan Bekasi juga menjadi wilayah yang banyak didatangi migran. Hal ini sesuai dengan hasil penelitian Frank (2004) mengenai arah migrasi internal yang menuju pusat pertumbuhan ekonomi di Indonesia. Dari hasil penelitian diketahui bahwa sebanyak $75 \%$ migran tidak hanya bermigrasi satu kali melainkan berpindah-pindah ke berbagai daerah untuk mencari lokasi dan pekerjaan yang lebih baik. Pada migrasi migran yang kedua, Bekasi menjadi daerah yang paling banyak disinggahi migran.

\section{Motivasi Migrasi}

Dalam bermigrasi, terdapat motivasi yang mendorong migran untuk pindah dari daerah asalnya ke daerah lain. Motivasi tersebut dapat dipengaruhi oleh faktor pendorong dari daerah asal maupun faktor penarik dari daerah tujuan. Meskipun begitu, dalam penelitian ini tidak dilihat apakah motivasi tersebut dipengaruhi oleh faktor pendorong dari daerah asal atau faktor penarik dari daerah tujuan. Saat meninggalkan kampung halaman, sebagian besar migran memiliki motif ekonomi berupa keinginan untuk mencari pekerjaan dan hanya sedikit migran yang bermigrasi dengan motif sosial berupa keinginan untuk mencari pengalaman karena daerah tujuan lebih ramai dan banyak hiburan. Selain kedua motif tersebut, terdapat juga migran yang meninggalkan kampung halaman karena ikut suami/ istri/orang tua dan migran yang bermigrasi karena ingin bersekolah. Motivasi migrasi berupa budaya merantau dan keinginan untuk mengubah status sosial tidak ditemukan dalam penelitian ini. Sejalan dengan motivasi saat meninggalkan kampung halaman, motivasi migran untuk bermigrasi ke Cikarang juga didominasi oleh motif ekonomi. Hal ini dikarenakan Cikarang yang dijuluki sebagai kota industri memiliki banyak pabrik dan menjadi salah satu pusat perekonomian di Indonesia sehingga menarik tenaga kerja dari berbagai daerah untuk datang. Motif ekonomi tersebut berupa keinginan untuk mencari pekerjaan, mengembangkan usaha/mencari lokasi usaha yang lebih baik dan agar lebih dekat dengan lokasi kerja.

\section{Jenis Migrasi}

Jenis migrasi dalam penelitian ini dibedakan atas migrasi musiman, sirkulasi dan migrasi permanen. Jenis migrasi dilihat berdasarkan frekuensi pulang kampung migran. Frekuensi pulang kampung dipengaruhi oleh pekerjaan migran. Migran yang memiliki pekerjaan yang fleksibel dan hari libur yang cukup panjang umumnya pulang kampung lebih dari atau sama dengan dua kali per tahun sehingga tergolong jenis mobilitas sirkulasi, sedangkan migran yang memiliki pekerjaan dengan jadwal yang padat umumnya pulang kampung hanya pada saat lebaran, bahkan belum tentu pulang kampung setiap tahun sehingga digolongkan dalam jenis migrasi permanen. Sementara itu, migran yang pulang kampung setiap ada kegiatan pertanian di kampung halamannya tergolong jenis migrasi musiman. Berdasarkan penelitian diketahui bahwa sebanyak $86,1 \%$ migran melakukan migrasi dengan jenis permanen. Migran-migran tersebut selain memiliki jam kerja yang kaku juga memiliki hari libur yang singkat sehingga tidak memungkinkan mereka untuk sering pulang ke Lampung. Sementara itu, migran yang melakukan mobilitas sirkulasi memiliki pekerjaan dengan jam kerja fleksibel atau memiliki hari libur yang cukup panjang.

\section{Strategi Adaptasi}

Ketika bermigrasi, migran membutuhkan strategi adaptasi agar mampu bertahan dan menyesuaikan diri dengan lingkungan baru. Adaptasi merupakan sebuah proses yang terjadi secara terus menerus dan tidak ada habisnya sehingga sulit untuk menetapkan indikator keberhasilan adaptasi. Oleh sebab itu, penelitian ini hanya melihat sejauh mana strategi adaptasi yang diterapkan migran di daerah tujuan migrasi.

\section{Pilihan Tempat Tinggal Migran}

Lingkungan tempat tinggal migran di daerah tujuan migrasi mempengaruhi proses adaptasi migran di daerah tersebut. Oleh sebab itu, salah satu strategi adaptasi yang diterapkan migran adalah dengan memilih tempat tinggal yang memberi keuntungan tersendiri bagi migran. Dalam penelitian ini, tempat tinggal migran dilihat berdasarkan tempat tinggal ketika migran pertama kali bermigrasi ke Cikarang dan tempat tinggal migran saat ini.

Ketika pertama kali bermigrasi ke Cikarang sebagian besar migran tinggal dengan migran sedaerah asalnya yang terdiri atas keluarga, saudara atau tetangga/teman sedaerah asalnya. Umumnya migran tinggal bersama dengan orang yang membantu proses migrasinya. Terdapat juga migran yang tinggal sendiri saat pertama kali bermigrasi ke Cikarang karena migran tidak memiliki saudara dekat di Cikarang atau karena migran merasa telah mandiri. Pada masa awal migrasi migran ke Cikarang, sebanyak 64\% migran memilih tempat tinggal sebagai strategi adaptasi ekonomi sementara 30,6\% migran memilih tempat tinggal sebagai strategi adaptasi sosial. Alasan ekonomi migran dalam memilih tempat tinggal adalah untuk berhemat, dekat dengan tempat kerja dan agar migran mudah mengakses informasi mengenai pekerjaan, sementara alasan sosial migran adalah agar mudah meminta bantuan sosial. Selain itu, terdapat juga migran yang tinggal bersama suami/istri mereka. Migran pada golongan ini tidak memilih tempat tinggal karena alasan ekonomi maupun sosial, melainkan karena kewajiban dan kemandiriannya untuk tinggal bersama suami/istri mereka.

Saat penelitian dilaksanakan sebanyak 27,8\% migran memilih tempat tinggal sebagai strategi adaptasi ekonomi dan 13,9\% migran memilih tempat tinggal sebagai strategi adaptasi sosial. Berkurangnya kedua strategi adaptasi dalam memilih tempat tinggal tersebut disebabkan karena pada saat penelitian dilaksanakan banyak migran yang telah berkeluarga dan tinggal bersama suami/istri mereka sehingga alasan mereka dalam memilih tempat tinggal lebih cenderung untuk mengakomodasi keluarganya, bukan sebagai strategi adaptasi.

\section{Keikutsertaan dalam Organisasi/Perkumpulan}

Strategi adaptasi lainnya yang diterapkan migran di lingkungan baru adalah dengan menjadi anggota dalam 
organisasi atau perkumpulan. Dengan terlibat dalam organisasi atau perkumpulan, migran dapat memperluas jaringan sosial sehingga memudahkan mereka dalam mengakses informasi dan meminta bantuan baik yang bersifat ekonomi maupun sosial. Perkumpulan yang menjadi fokus dalam penelitian ini adalah perkumpulan khusus migran sedaerah asal, perkumpulan pekerja yang seprofesi dan perkumpulan masyarakat di sekitar tempat tinggal. Jumlah migran yang mengikuti perkumpulan khusus migran sedaerah asalnya adalah sebanyak 36,1\%, jumlah migran yang mengikuti organisasi atau perkumpulan dengan pekerja yang seprofesi adalah sebanyak $25 \%$ dan migran yang mengikuti organisasi atau perkumpulan di lingkungan tempat tinggal adalah sebanyak 58.3\%.

Sebanyak 50\% migran yang tidak mengikuti perkumpulan dengan migran sedaerah asalnya mengaku tidak ada perkumpulan migran Lampung di sekitar tempat tinggal mereka dan 13,9\% lainnya tidak mengikuti perkumpulan dengan migran sedaerah asalnya karena tidak diajak atau lokasinya terlalu jauh. Sementara itu, sebanyak 72,2\% migran yang tidak mengikuti organisasi/perkumpulan dengan pekerja yang seprofesi tidak mengikuti perkumpulan karena tidak ada perkumpulan sesama pekerja di lingkungan kerja mereka dan 2,8\% lainnya tidak mengikuti perkumpulan ini karena tidak diajak. Di lain pihak, sebanyak 33,3\% migran tidak ikut serta dalam perkumpulan di lingkungan tempat tinggalnya karena sibuk bekerja dan 8,4\% lainnya tidak mengikuti perkumpulan ini karena malas dan tidak diajak.

Dari hasil penelitian diketahui bahwa hampir semua perkumpulan yang yang diikuti migran merupakan perkumpulan informal. Hanya ada lima organisasi/ perkumpulan formal yang teridentifikasi dalam penelitian ini, antara lain struktur RT, GEMUL (paguyuban migran asal Desa Lumbok), serikat pekerja, Dewan Keluarga Masjid dan partai politik. Perkumpulan yang diikuti migran terdiri atas arisan, pengajian, paguyuban, struktur RT, Dewan Keluarga Masjid, kepanitiaan acara di lingkungan tempat tinggal dan kelompok olah raga.

Dari penelitian didapat data bahwa secara umum migran yang ikut serta dalam organisasi/perkumpulan untuk alasan sosial lebih banyak dibandingkan migran yang menjadi anggota organisasi/perkumpulan untuk alasan ekonomi. Alasan sosial yang mendasari migran untuk mengikuti suatu organisasi/perkumpulan adalah untuk menambah teman atau bersilaturahmi dan agar mudah meminta bantuan, sementara alasan ekonomi yang mendasari migran untuk mengikuti perkumpulan tersebut adalah agar mudah mendapatkan informasi yang berkaitan dengan pekerjaan dan sebagai strategi memanajemen keuangan migran.

Di lingkungan tempat tinggal, selain mengikuti perkumpulan masyarakat sekitar, migran juga mengikuti kegiatan kemasyarakatan seperti iuran warga dan kegiatan olah raga. Kegiatan sosial lainnya seperti kerja bakti atau bakti sosial dan ronda untuk warga yang laki-laki tidak lagi dilaksanakan karena secara umum tempat tinggal migran berupa kompleks yang memiliki bagian keamanan dan kebersihan yang mengambil alih tugas tersebut. Meskipun begitu, tidak semua migran terlibat dalam kegiatan masyarakat yang telah disebutkan sebelumnya. Terdapat $16,7 \%$ migran yang tidak terlibat dalam kegiatan kemasyarakatan. Dari jumlah tersebut, $11,1 \%$ di antaranya tidak mengikuti kegiatan kemasyarakatan karena sibuk bekerja, sementara sisanya tidak mengikuti kegiatan tersebut karena tidak bisa berbaur dengan masyarakat atau tidak ada kegiatan kemasyarakatan di lingkungan tempat tinggal mereka.

\section{Jenis Bantuan}

Migran memilih tempat tinggal yang berdekatan dengan jaringan sosialnya dan mengikuti berbagai perkumpulan agar mudah meminta bantuan jika mereka dalam kesulitan, baik dalam hal ekonomi maupun sosial. Bantuan yang diberikan oleh jaringan sosial migran pun beragam. Hampir seluruh bantuan yang diterima migran tergolong sebagai bantuan ekonomi. Hanya terdapat satu bantuan sosial yang diberikan oleh jaringan sosial migran, yaitu bantuan tenaga jika ada insiden tertentu. Bantuan tersebut pun hanya diterima oleh 13,9\% migran. Bantuan sosial lain seperti dibantu mendekatkan dengan masyarakat dan dibantu menyesuaikan diri dengan lingkungan baru tidak ditemukan dalam penelitian ini. Berdasarkan penelitian, diketahui bahwa sebanyak $19,4 \%$ migran tidak mendapat bantuan apa pun, sementara $27,8 \%$ migran hanya mendapat satu bentuk bantuan dan $52,8 \%$ migran mendapat bantuan lebih dari satu.

Dalam penelitian ini, bantuan dibedakan berdasarkan jenisnya, yaitu bantuan ekonomi dan sosial. Bantuan ekonomi yang diterima migran lebih banyak dibandingkan bantuan sosial. Bantuan ekonomi tersebut berupa tumpangan tempat tinggal sementara, dicukupi kebutuhan makan sementara, dicarikan pekerjaan, diberi informasi yang berkaitan dengan pekerjaan dan dipinjami uang, sementara bantuan sosial yang didapat migran berupa tenaga jika migran mengalami insiden tertentu (meninggal, sakit, persiapan pesta/syukuran dan lain-lain). Terdapat juga migran yang tidak mendapat bantuan karena migran tidak memiliki jaringan sosial yang cukup dekat sehingga tidak ada yang bisa dimintai tolong oleh migran. Berdasarkan tingkatannya, bantuan yang diterima migran didominasi oleh tingkat rendah di mana 19,4\% migran tidak mendapat bantuan apapun dan 25\% migran hanya mendapat satu bentuk bantuan yang jenisnya berupa bantuan ekonomi.

\section{Pilihan Pekerjaan}

Motivasi migran dalam bermigrasi didominasi oleh motif ekonomi berupa keinginan untuk mencari pekerjaan. Kurun waktu migran dalam mendapatkan pekerjaan di daerah tujuan migrasi cukup beragam. Ada yang kurang dari satu bulan dan ada yang mencapai hitungan tahun. Setelah bermigrasi, sebagian besar migran mendapatkan pekerjaan kurang dari dua bulan. Migran bisa mendapatkan pekerjaan dalam waktu yang singkat karena bantuan dari jaringan sosial mereka dan didukung dengan usaha mereka dalam mencari informasi dan tingkat pendidikan mereka yang cukup memadai. Satu orang di antaranya bahkan mengaku memberi uang sogokan sehingga ia dengan mudah mendapatkan pekerjaan. Terdapat pula satu migran yang sulit mendapat pekerjaan karena stereotipe dirinya sebagai orang Sumatra yang dianggap keras dan sukar diatur. Di lain pihak, migran yang mendapat pekerjaan dalam hitungan tahun setelahmbermigrasi adalah migran yang bermigrasi pada usia sekolah dan mereka mendapat pekerjaan beberapa tahun kemudian setelah menyelesaikan sekolah mereka.

Lokasi yang menjadi daerah tujuan migrasi migran adalah 
wilayah yang memiliki lapangan pekerjaan yang besar yang umumnya berupa wilayah industri yang memiliki banyak pabrik seperti Cikarang. Adanya banyak pabrik di daerah ini menarik tenaga kerja untuk datang ke Cikarang karena banyak tersedia lapangan pekerjaan. Tidak hanya itu, kondisi Cikarang yang ramai memberi peluang yang besar untuk membuka usaha. Kebanyakan migran bekerja sebagai buruh pabrik setelah pindah ke Cikarang karena terdapat banyak lapangan pekerjaan sebagai buruh pabrik di kota tersebut. Sebanyak 41,7\% migran memilih pekerjaan ini karena mengikuti migran terdahulu, sementara sebanyak $22,2 \%$ migran tidak memiliki pilihan pekerjaan lain yang bisa mereka lakukan sehingga mereka memilih pekerjaan ini.

Sementara itu, sebanyak 13,9\% migran bekerja sebagai pedagang. Selain alasan ikut kerabat, migran menggeluti pekerjaan ini karena melihat peluang dan mempertimbangkan waktu kerjanya yang fleksibel. Sebanyak 8,3\% migran bekerja sebagai wiraswasta. Wiraswasta yang dimaksud di sini adalah pekerjaan sebagai "bank berjalan". Migran menjalankan usaha ini karena mengikuti teman atau kerabatnya. Sebagai sesama wiraswasta mereka saling memberi informasi yang dapat membantu usaha mereka. Pekerjaan lain yang digeluti migran adalah pekerjaan sebagai kontraktor, satpam, pemilik dan pekerja toko bunga, pemilik salon dan membuka bisnis arisan. Tingkat pendidikan migran yang umumnya tidak terlalu tinggi membuat mereka tidak dapat bekerja sebagai karyawan perusahaan atau bekerja di instansi pemerintah.

Seiring berjalannya waktu, beberapa migran mengembangkan strategi adaptasi mereka dengan berganti pekerjaan, menerapkan pola nafkah ganda dan memaksimalkan jam kerja. Alasan migran ketika berganti pekerjaan cukup beragam, di antaranya karena migran ingin mencari lokasi kerja yang memberi penghasilan lebih tinggi, karena migran merasa kurang nyaman dengan lokasi kerja sebelumnya, karena pertimbangan waktu kerja atau karena di-PHK dari lokasi kerja sebelumnya. Di lain pihak, pola nafkah ganda dilakukan untuk menambah penghasilan migran dan mengembangkan usaha mereka. Sebagian besar migrant juga bekerja lebih dari 8 jam per hari dan beberapa migran tidak memiliki hari libur kerja. Hal ini selain dilakukan untuk menambah penghasilan migran dan untuk mengisi waktu mereka, juga dilakukan karena kontrak kerja yang mewajibkan mereka untuk bekerja melebihi jam kerja normal.

\section{Prioritas Adaptasi}

Dalam penelitian ini, adaptasi dibedakan menjadi adaptasi ekonomi dan adaptasi sosial. Migran yang memprioritaskan adaptasi sosialnya adalah migran yang mengutamakan kehidupan sosial yang stabil lebih dulu, sedangkan migran yang memprioritaskan adaptasi ekonominya adalah migran yang memilih memapankan pekerjaan/usahanya lebih dahulu. Kedua adaptasi ini tidak selalu berlawanan. Jika salah satu adaptasi tinggi, belum tentu adaptasi lainnya akan rendah karena kedua adaptasi ini dapat berjalan bersisian. Seseorang mungkin memiliki adaptasi ekonomi yang tinggi namun dapat memiliki adaptasi sosial yang tinggi pula dan seseorang mungkin memiliki adaptasi ekonomi yang rendah namun dapat memiliki adaptasi sosial yang rendah pula. Meskipun begitu, umumnya migran harus memilih salah satu adaptasi karena keterbatasan waktu untuk menjalankan strategi adaptasi tersebut.

Sebanyak 86,1\% migran memilih memapankan pekerjaan/usahanya terlebih dahulu, sementara $11,1 \%$ migran memilih membina hubungan yang dekat dengan masyarakat untuk memapankan kehidupan sosialnya dan 2,8\% migran memilih keduanya. Data ini didapat dengan menanyakan pilihan migran secara langsung, namun untuk melihat prioritas adaptasi tidak hanya dengan menanyakan pilihan migran saja melainkan dengan melihat strategi adaptasi yang dilakukan dan alasan yang mendasari migran untuk melakukan strategi adaptasi tersebut, apakah untuk alasan ekonomi atau untuk alasan sosial. Dengan melihat hal tersebut maka didapat data mengenai adaptasi sebagai berikut.

1. Migran yang tingkat adaptasi ekonomi dan adaptasi sosialnya rendah adalah sebanyak $2,8 \%$. Migran ini adalah migran yang tidak banyak menerapkan strategi adaptasi ekonomi dan strategi adaptasi sosial.

2. Migran yang tingkat adaptasi ekonominya rendah namun tingkat adaptasi sosialnya sedang adalah sebanyak 16,7\%. Migran pada golongan ini adalah migran yang menerapkan strategi adaptasi untuk alasan sosial lebih banyak dibandingkan untuk alasan ekonomi.

3. Migran yang menerapkan strategi adaptasi untuk alasan ekonomi lebih banyak dibandingkan untuk alasan sosial adalah sebanyak $63,9 \%$. Kondisi di mana tingkat adaptasi ekonomi migran sedang dan adaptasi sosialnya rendah ini adalah kondisi yang paling dominan dialami oleh migran dalam penelitian ini. Hal ini mengindikasikan bahwa sebagian besar migran lebih memprioritaskan adaptasi ekonomi daripada adaptasi sosial.

4. Migran yang tingkat adaptasi sosialnya tinggi dan adaptasi ekonominya sedang sebanyak $11,1 \%$. Migran ini memiliki tingkat adaptasi yang baik, baik untuk kondisi sosial maupun kondisi ekonominya, meskipun strategi adaptasi sosialnya lebih baik dibandingkan adaptasi ekonominya.

5. Migran yang tingkat adaptasi ekonominya tinggi namun tingkat adaptasi sosialnya rendah adalah sebanyak 5,6\%. Migran ini adalah migran yang sibuk bekerja dan kurang memperhatikan kehidupan sosialnya di lingkungan masyarakat.

Seperti yang telah dinyatakan dalam hipotesis, dalam penelitian ini penulis menghubungkan karakteristik migran dengan prioritas adaptasi untuk melihat ada atau tidaknya pengaruh karakteristik migran terhadap prioritas adaptasi. Karakteristik yang dihubungkan dengan prioritas adaptasi adalah karakteristik migran saat penelitian dilaksanakan karena adaptasi yang dilakukan migran dalam rentang waktu antara tahun kepergian migran dari kampung halamannya dengan saat penelitian dilaksanakan lebih signifikan.

Berdasarkan Tabel 2, terlihat bahwa dalam hampir semua karakteristik, migran cenderung memprioritaskan adaptasi ekonomi. Hanya satu kategori di mana migran memilih adaptasi sosial sebagai prioritasnya, yaitu dalam karakteristik pendidikan pada tingkat sarjana. 
Data ini menunjukkan bahwa tidak terdapat hubungan antara karakteristik migran dengan prioritas adaptasi yang menjadi fokus perhatian migran. Umumnya migran lebih memilih memapankan pekerjaan dan kehidupan ekonominya dibandingkan mengakrabkan diri dengan lingkungan sekitarnya dalam rangka mencapai kehidupan sosial yang stabil.

\section{Jaringan Sosial Migran}

\section{Besarnya Jaringan Sosial}

Jaringan sosial merupakan faktor penting dalam dalam kehidupan manusia. Keberadaan jaringan sosial berpengaruh besar bagi seseorang terutama ketika orang tersebut memerlukan bantuan. Dalam penelitian ini jaringan sosial dibedakan atas migran sedaerah asal, teman di lingkungan kerja dan masyarakat di lingkungan tempat tinggal.

Salah satu alat ukur dalam mengukur fenomena yang berkaitan dengan jaringan sosial adalah dengan melihat besarnya jaringan sosial, yaitu jumlah orang yang terlibat dalam jaringan sosial tersebut. Seperti yang telah disebutkan dalam tinjauan pustaka, beberapa migran telah memiliki jaringan sosial di daerah tujuan migrasi bahkan sebelum mereka bermigrasi ke daerah tersebut.

Tabel 2. Jumlah Migran Menurut Karakteristik Saat Penelitian Dilaksanakan dan Prioritas Adaptasi, Desa Jayamukti, 2011

\begin{tabular}{|c|c|c|c|c|c|c|}
\hline \multirow{3}{*}{$\begin{array}{c}\text { Karakteristik } \\
\text { Migran }\end{array}$} & \multicolumn{6}{|c|}{ Prioritas adapatasi } \\
\hline & \multicolumn{2}{|c|}{ Ekonomi } & \multicolumn{2}{|c|}{ Sosial } & \multicolumn{2}{|c|}{ Total } \\
\hline & $\mathrm{n}$ & $\%$ & $\mathrm{n}$ & $\%$ & $\mathrm{n}$ & $\%$ \\
\hline \multicolumn{7}{|l|}{ Jenis Kelamin } \\
\hline Laki-laki & 11 & 68.8 & 5 & 31.3 & 16 & 100 \\
\hline Perempuan & 15 & 75 & 5 & 25 & 20 & 100 \\
\hline \multicolumn{7}{|c|}{ Pendidikan terakhir } \\
\hline SMP & 2 & 66.7 & 1 & 33.3 & 3 & 100 \\
\hline SMA & 20 & 76.9 & 6 & 23.1 & 26 & 100 \\
\hline Diploma & 3 & 75 & 1 & 25 & 4 & 100 \\
\hline Sarjana & 1 & 33.3 & 2 & 66.7 & 3 & 100 \\
\hline \multicolumn{7}{|c|}{ Status Perkawinan } \\
\hline Belum menikah & 5 & 100 & 0 & 0 & 7 & 100 \\
\hline Menikah & 19 & 65.5 & 10 & 34.5 & 17 & 100 \\
\hline Duda/janda & 2 & 100 & 0 & 0 & 12 & 100 \\
\hline \multicolumn{7}{|l|}{ Usia } \\
\hline$<24$ thn & 7 & 100 & 0 & 0 & 7 & 100 \\
\hline $24-35$ thn & 12 & 70.6 & 5 & 29.4 & 17 & 100 \\
\hline$>35$ thn & 7 & 58.3 & 5 & 41.7 & 12 & 100 \\
\hline \multicolumn{7}{|l|}{ Pendapatan } \\
\hline$<1.5$ juta & 8 & 88.9 & 1 & 11.1 & 10 & 100 \\
\hline $1.5-4$ juta & 11 & 68.8 & 5 & 31.3 & 16 & 100 \\
\hline$>4$ juta & 7 & 63.6 & 4 & 36.4 & 11 & 100 \\
\hline
\end{tabular}

Keberadaan jaringan sosial di daerah tujuan menjadi salah satu faktor penarik migrasi. Dalam penelitian ini, besar jaringan sosial migran di Cikarang dilihat dalam dua kondisi, yaitu sebelum migran bermigrasi ke Cikarang dan saat penelitian dilaksanakan. Sebelum bermigrasi ke Cikarang, sebanyak 27,8\% migran tidak memiliki jaringan sosial di Cikarang, sedangkan $72,2 \%$ lainnya memiliki jaringan sosial di Cikarang dengan jumlah yang beragam. Seiring berjalannya waktu, yaitu sejak awal migrasi migran ke Cikarang hingga saat penelitian dilaksanakan, jumlah orang yang dikenal migran di Cikarang semakin bertambah.

Jaringan sosial yang semakin besar dipengaruhi oleh interaksi atau pergaulan migran di lingkungan yang baru, baik dengan migran sedaerah asal, teman di lingkungan kerja, maupun masyarakat di lingkungan tempat tinggal. Saat penelitian dilaksanakan, sebagian besar migran mengenal 100-250 orang di Cikarang. Umumnya migran yang sebagian besar bekerja sebagai buruh pabrik tersebut mencurahkan sebagian besar waktunya untuk bekerja sehingga interaksi mereka hanya sebatas interaksi dengan rekan kerja dan tetangga di sekitar tempat tinggal mereka.

Berdasarkan studi literatur, semakin banyak orang yang dikenal maka semakin banyak juga bantuan yang akan diterima oleh migran sehingga akan memudahkan adaptasi mereka di lingkungan baru, namun dengan menghubungkan data mengenai besar jaringan sosial dengan jumlah bantuan yang diterima migran diketahui bahwa tidak terdapat hubungan antara besarnya jaringan sosial dengan jumlah bantuan yang diterima migran.

Tabel 3. Jumlah Responden Menurut Besar Jaringan Sosial dan Tingkat Bantuan yang Diterima, Desa Jaya Mukti, 2011

\begin{tabular}{|c|c|c|c|c|c|c|c|c|}
\hline \multirow{3}{*}{$\begin{array}{c}\text { Besar } \\
\text { Jaringan } \\
\text { Sosial }\end{array}$} & \multicolumn{8}{|c|}{ Tingkat Bantuan yang Diterima } \\
\hline & \multicolumn{2}{|c|}{ Rendah } & \multicolumn{2}{|c|}{ Sedang } & \multicolumn{2}{|c|}{ Tinggi } & \multicolumn{2}{|c|}{ Jumlah } \\
\hline & $\mathrm{n}$ & $\%$ & $\mathrm{n}$ & $\%$ & $\mathrm{n}$ & $\%$ & $\mathrm{n}$ & $\%$ \\
\hline $\begin{array}{l}\text { Kecil } \\
(<100 \\
\text { orang) }\end{array}$ & 1 & 50 & 0 & 0 & 1 & 50 & 2 & 100 \\
\hline $\begin{array}{l}\text { Sedang } \\
\text { (100-500 } \\
\text { orang) }\end{array}$ & 11 & 40.7 & 8 & 29.6 & 8 & 29.6 & 27 & 100 \\
\hline $\begin{array}{l}\text { Besar } \\
(>500 \\
\text { orang) }\end{array}$ & 4 & 57.1 & 1 & 14.3 & 2 & 28.6 & 7 & 100 \\
\hline Jumlah & 16 & 44.4 & 9 & 25 & 11 & 30.6 & 36 & 100 \\
\hline
\end{tabular}

Data penelitian menunjukkan bahwa besar jaringan sosial migran didominasi oleh tingkat sedang, namun jumlah bantuan yang diterima sebagian besar migran berada pada tingkat yang rendah. Karena bantuan dari jaringan sosial akan memudahkan migran dalam beradaptasi di lingkungan baru, maka dapat dikatakan bahwa besar jaringan sosial tidak berpengaruh pada adaptasi migran. Meskipun migran mengenal banyak orang namun belum tentu migran memiliki hubungan yang dekat atau interaksi yang cukup intensif dengan orang-orang tersebut. Bantuan umumnya datang dari jaringan sosial migran yang memiliki hubungan dekat dan intensitas interaksi yang tinggi dengan migran.

\section{Kedekatan Migran dengan Jaringan Sosial}

Alat ukur lain dalam menggambarkan fenomena yang 
berhubungan dengan jaringan sosial adalah kedekatan migran dengan jaringan sosialnya. Kedekatan migran dengan jaringan sosialnya dibedakan berdasarkan status hubungan migran dengan jaringan sosialnya yang terdiri atas keluarga, saudara dan teman atau tetangga. Yang dimaksud dengan keluarga dalam penelitian ini adalah keluarga inti migran atau seseorang yang memiliki hubungan darah atau ikatan pernikahan dengan migran, sementara yang dimaksud dengan saudara adalah sesorang yang memiliki hubungan kekerabatan dengan migran dan teman/tetangga yang dimaksud adalah teman/tetangga migran di daerah asal dan di daerah tujuan. Hasil studi literatur menunjukkan bahwa kedekatan migran dengan jaringan sosialnya dapat mempengaruhi jumlah bantuan yang diterima migran di mana semakin dekat hubungan migran dengan jaringan sosialnya maka semakin banyak bantuan yang diterima migran. Data mengenai hubungan antara tingkat kedekatan migran dengan jaringan sosialnya dan bantuan yang diterima migran dapat dilihat dalam tabel berikut.

Berdasarkan data yang tertera pada tabel di atas, terlihat bahwa dalam penelitian ini tidak terdapat hubungan antara kedekatan hubungan migran dengan jaringan sosialnya dan jumlah bantuan yang diterima. Kedekatan migran dengan jaringan sosialnya didominasi oleh tingkat sedang, namun bantuan yang diterima migran didominasi oleh tingkat rendah. Kedekatan hubungan migran dengan jaringan sosialnya tidak berpengaruh pada jumlah bantuan yang diterima migran karena sifat migran dan jaringan sosialnya yang individualis. Berdasarkan temuan di lapangan, migran yang sebagian besar telah menikah dan tinggal terpisah dengan migran sedaerah asalnya jarang berinteraksi dengan migran sedaerah asal dan masyarakat di sekitar tempat tinggalnya.

Tabel 4. Jumlah Migran Menurut Tingkat Kedekatan dengan Jaringan Sosial dan Tingkat Bantuan yang Diterima, Desa Jaya Mukti, 2011

\begin{tabular}{lrrrrrrrr}
\hline Tingkat & \multicolumn{8}{c}{ Tingkat Bantuan yang Diterima } \\
\cline { 2 - 9 } $\begin{array}{c}\text { Kedekatan } \\
\text { dengan }\end{array}$ & \multicolumn{1}{c}{ Rendah } & \multicolumn{2}{c}{ Sedang } & \multicolumn{2}{c}{ Tinggi } & \multicolumn{2}{c}{ Jumlah } \\
\cline { 2 - 9 } $\begin{array}{c}\text { Jaringan } \\
\text { Sosial }\end{array}$ & $\mathrm{n}$ & $\%$ & $\mathrm{n}$ & $\%$ & $\mathrm{n}$ & $\%$ & $\mathrm{n}$ & $\%$ \\
\hline Rendah & 3 & 60 & 1 & 20 & 1 & 20 & 5 & 100 \\
Sedang & 10 & 58.8 & 4 & 23.5 & 3 & 17.6 & 17 & 100 \\
Tinggi & 3 & 21.4 & 4 & 28.6 & 7 & 50.7 & 14 & 100 \\
Jumlah & 16 & 44.4 & 9 & 25 & 11 & 30.6 & 36 & 100 \\
\hline
\end{tabular}

Minimnya interaksi migran dengan jaringan sosialnya menyebabkan kepekaan antara migran dan jaringan sosialnya akan kondisi satu sama lain juga rendah. Pada masa awal migrasi jaringan sosial migran memberikan bantuan yang cukup bagi migran, namun dalam masa perkembangannya bantuan yang diberikan hanya bersifat insidental.

\section{Fungsi Jaringan Sosial}

Jaringan sosial memiliki fungsi-fungsi dalam kehidupan migran di daerah tempat tinggalnya yang baru. Fungsi tersebut dapat dilihat berdasarkan jenis bantuan yang diberikan oleh jaringan sosial migran. Fungsi jaringan sosial dibedakan menjadi fungsi ekonomi, fungsi sosial dan fungsi informasi. Pada masa awal migrasi migran ke Cikarang fungsi jaringan sosial lebih diutamakan untuk membantu migran agar dapat bertahan di lingkungan yang baru, sementara setelah cukup lama tinggal di Cikarang fungsi jaringan sosial dapat berubah dan berkembang sesuai dengan perkembangan kondisi migran selama tinggal di Cikarang. Oleh sebab itu, dalam penelitian ini fungsi jaringan sosial dilihat dalam dua kondisi, yaitu pada masa awal migrasi migran ke Cikarang dan saat penelitian dilaksanakan.

Pada saat meninggalkan kampung halaman, sebagian besar migran mendapat bantuan dalam proses migrasinya, namun setelah itu sebanyak $19,4 \%$ migran mengaku tidak mendapat bantuan lagi dari jaringan sosialnya pada masa- masa awal mereka tinggal di Cikarang. Enam migran yang tidak mendapat bantuan pada masa awal migrasinya mengaku telah mandiri dan lima di antaranya telah berkeluarga sehingga mereka tidak lagi bergantung pada bantuan dari jaringan sosialnya. Sementara itu, satu migran tidak memiliki jaringan sosial yang dekat dan bisa dimintai tolong. Migran tersebut mengaku bahwa masyarakat di sekitar tempat tinggalnya memiliki sifat individualis dan kurang peka terhadap kondisi orang lain sehingga ia sungkan untuk meminta pertolongan dari tetangga di sekitar tempat tinggalnya. Migran yang memiliki jaringan sosial dengan fungsi ekonomi adalah sebesar $77,8 \%$. Migran ini adalah migran yang mendapat bantuan ekonomi dari jaringan sosialnya berupa tempat tinggal sementara dan ketersediaan makanan yang berfungsi sebagai strategi berhemat migran. Selain itu, sebanyak sembilan migran diberi atau dicarikan pekerjaan oleh jaringan sosialnya. Migran yang memiliki jaringan sosial dengan fungsi sosial adalah sebesar $41,7 \%$. Migranmigran ini memanfaatkan bantuan berupa tumpangan tempat tinggal sementara yang mereka dapat bukan hanya untuk alasan ekonomi saja tetapi juga dimanfaatkan untuk alasan sosial, di antaranya agar mudah meminta bantuan tenaga dari jaringan sosial mereka. Sementara itu, migran yang memiliki jaringan sosial dengan fungsi informasi adalah sebesar 30,6\%. Dalam kaitannya dengan informasi, jaringan sosial migran umumnya memberikan informasi yang berkaitan dengan pekerjaan.

Pada saat penelitian dilaksanakan, jumlah migran yang memiliki jaringan sosial yang disfungsi, atau dengan kata lain tidak memiliki fungsi dalam membantu adaptasi migran, naik menjadi 50\%. Kondisi ini disebabkan banyak migran yang telah mandiri sehingga migran tidak lagi bergantung pada bantuan yang diberikan oleh jaringan sosialnya. Migran yang memiliki jaringan sosial dengan fungsi ekonomi turun menjadi 47,2\%. Hal ini disebabkan banyak migran yang telah berkeluarga dan tidak lagi tinggal bersama jaringan sosialnya sehingga jaringan sosial migran tidak lagi berperan dalam strategi berhemat migran. Jaringan sosial migran hanya memberikan bantuan berupa pinjaman uang jika migran membutuhkannya. Sementara itu, migran yang memiliki jaringan sosial dengan fungsi sosial turun menjadi $13,9 \%$. Bantuan sosial yang diberikan jaringan sosial kepada migran hampir seluruhnya terjadi ketika migran mengalami insiden seperti sakit, ada keluarga yang meninggal atau melahirkan dan insiden lainnya, namun insiden seperti itu jarang terjadi sehingga bantuan jaringan sosial untuk adaptasi sosial migran sedikit. Sementara itu tidak ada migran yang memiliki jaringan sosial dengan fungsi informasi. Hal ini disebabkan seluruh migran dalam 
penelitian ini telah memiliki pekerjaan sehingga mereka tidak membutuhkan informasi mengenai pekerjaan dari jaringan sosialnya lagi.

Tabel 5. Jumlah Migran Menurut Fungsi Jaringan Sosial pada Awal Migrasi ke Cikarang dan Saat Penelitian Dilaksanakan, Desa Jayamukti, 2011

\begin{tabular}{lccrr}
\hline \multirow{2}{*}{$\begin{array}{c}\text { Fungsi Jaringan } \\
\text { Sosial }\end{array}$} & \multicolumn{2}{c}{$\begin{array}{c}\text { Saat Awal Migrasi } \\
\text { ke Cikarang }\end{array}$} & \multicolumn{2}{c}{$\begin{array}{c}\text { Saat Penelitian } \\
\text { Dilaksanakan }\end{array}$} \\
\cline { 2 - 5 } & $\mathrm{n}$ & $\%$ & $\mathrm{n}$ & $\%$ \\
\hline Disfungsi & 7 & 19.4 & 18 & 50 \\
Fungsi ekonomi & 28 & 77.8 & 17 & 47.2 \\
Fungsi sosial & 15 & 41.7 & 5 & 13.9 \\
Fungsi informasi & 11 & 30.6 & 0 & 0 \\
\hline
\end{tabular}

Fungsi jaringan sosial migran juga dilihat berdasarkan tingkatannya. Tingkat tersebut dinilai berdasarkan banyaknya fungsi yang dijalankan oleh jaringan sosial migran. Fungsi jaringan sosial dikatakan rendah jika jaringan sosial tidak berfungsi atau hanya memiliki satu jenis fungsi saja dan fungsi jaringan sosial dikatakan sedang jika jaringan sosial memiliki dua jenis fungsi, contohnya fungsi ekonomi dan sosial atau fungsi ekonomi dan informasi. Sementara itu, fungsi jaringan sosial dikatakan tinggi jika jaringan sosial memiliki semua fungsi yang dapat memudahkan kehidupan migran di Cikarang.

Pada masa awal tinggal di Cikarang, banyak migran yang tidak mendapat bantuan atau hanya mendapat bantuan di salah satu bidang saja sehingga sebagian besar jaringan sosial migran memiliki fungsi yang rendah dan kondisi ini meningkat pada saat penelitian dilaksanakan. Hal ini disebabkan banyak migran yang tidak lagi tinggal dengan jaringan sosialnya sehingga peran jaringan sosial dalam proses adaptasi migran berkurang. Sementara itu, migran yang memiliki jaringan sosial dengan tingkat yang sedang pada masa awal tinggal di Cikarang adalah sebanyak sebelas orang dan jumlah ini menurun pada saat penelitian dilaksanakan.

Tabel 6. Jumlah Migran Menurut Tingkat Fungsi Jaringan Sosial pada Masa Awal Migrasi ke Cikarang dan Saat Penelitian Dilaksanakan, Desa Jayamukti 2011

\begin{tabular}{|c|c|c|c|c|c|c|}
\hline \multirow{3}{*}{$\begin{array}{l}\text { Tingkat Fungsi Ja- } \\
\text { ringan Sosial pada } \\
\text { Masa Awal Migrasi } \\
\text { ke Cikarang }\end{array}$} & \multicolumn{6}{|c|}{$\begin{array}{c}\text { Tingkat Fungsi Jaringan Sosial Saat } \\
\text { Penelitian Dilaksanakan }\end{array}$} \\
\hline & \multicolumn{2}{|c|}{ Rendah } & \multicolumn{2}{|r|}{ Sedang } & \multicolumn{2}{|c|}{ Jumlah } \\
\hline & $\mathrm{n}$ & $\%$ & $\mathrm{n}$ & $\%$ & $\mathrm{n}$ & $\%$ \\
\hline Rendah & 7 & 19.4 & 18 & 50 & 18 & 100 \\
\hline Sedang & 28 & 77.8 & 17 & 47.2 & 11 & 100 \\
\hline Tinggi & 15 & 41.7 & 5 & 13.9 & 7 & 100 \\
\hline Jumlah & 32 & 88.9 & 4 & 11.1 & 36 & 100 \\
\hline
\end{tabular}

Jaringan sosial yang tadinya ikut membantu dalam adaptasi sosial migran menjadi berkurang fungsinya karena migran sudah lebih mandiri sehingga bisa mengembangkan kehidupan sosialnya tanpa bantuan jaringan sosial. Selain itu, pada saat penelitian dilaksanakan, fungsi jaringan sosial sebagai sumber informasi pekerjaan bagi migran juga berkurang, bahkan tidak ada sama sekali karena seluruh migran telah memiliki pekerjaan sehingga tidak membutuhkan informasi pekerjaan lagi. Dengan hilangnya salah satu fungsi jaringan sosial, yaitu fungsi informasi, maka pada saat penelitian dilaksanakan tidak ada migran yang memiliki jaringan sosial dengan fungsi yang tinggi.

\section{KESIMPULAN DAN SARAN}

Dalam bermigrasi, faktor usia dan keberadaan migran terdahulu di daerah tujuan migrasi mempengaruhi keputusan bermigrasi. Di daerah tujuan migrasi, migran umumnya tinggal dengan migran terdahulu yang juga berperan dalam proses migrasi migran. Tinggal sementara di tempat tinggal migran terdahulu merupakan salah satu strategi adaptasi migran. Dengan menumpang tinggal di tempat tinggal migran terdahulu, migran baru dapat berhemat dan lebih mudah mendapat pekerjaan karena bantuan dari migran terdahulu sebagai jaringan sosialnya. Selain dengan memilih tempat tinggal yang memberi keuntungan tersendiri bagi migran, strategi adaptasi yang dilakukan adalah dengan mengikuti berbagai organisasi atau perkumpulan untuk mengembangkan jaringan sosial. Hal ini selain dilakukan untuk bersilaturahmi dengan jaringan sosialnya juga agar migran mudah meminta bantuan. Sementara itu, strategi yang diterapkan migran dalam pekerjaannya adalah dengan berganti pekerjaan jika terdapat pekerjaan yang lebih baik daripada pekerjaan sebelumnya, baik dari segi ekonomi maupun sosial. Beberapa migran juga menerapkan pola nafkah ganda dan memaksimalkan jam kerja agar penghasilan yang didapat lebih besar.

Adaptasi dibedakan menjadi dua jenis, yaitu adaptasi ekonomi dan adaptasi sosial. Di daerah tujuan migrasi, sebagian besar migran lebih memprioritaskan adaptasi ekonomi mereka dari pada adaptasi sosial. Migran lebih memilih mengalokasikan sebagian besar waktunya untuk bekerja dan hanya sedikit di antaranya yang membina keakraban dengan masyarakat di sekitar tempat tinggalnya. Sebagian besar migran beranggapan bahwa selama mereka tidak membuat masalah dengan masyarakat, tidak akan ada hambatan bagi mereka di daerah tujuan migrasi meskipun mereka tidak membina hubungan yang akrab dengan masyarakat.

Jaringan sosial migran memiliki peran dalam proses adaptasi migran di lingkungan baru, namun dalam penelitian ini sebagian besar migran memiliki jaringan sosial dengan tingkat fungsi yang rendah. Bantuan yang didapat migran dari jaringan sosialnya selama berada di Cikarang pun tidak banyak. Hal ini disebabkan perilaku migran yang mandiri dan individual. Bantuan banyak diberikan pada masa awal migrasi migran ke Cikarang, namun setelahnya bantuan yang diberikan banyak berkurang. Migran mengalokasikan sebagian besar waktunya untuk bekerja sehingga intensitas interaksi mereka dengan jaringan sosialnya rendah. Hal ini menyebabkan kepekaan antara migran dan jaringan sosialnya terhadap kondisi masingmasing menjadi minim sehingga bantuan yang diterima pun sedikit. Adaptasi merupakan suatu konsep yang kompleks dan abstrak. Pada tulisan ini terdapat kelemahan sehingga tidak menggambarkan keadaan adaptasi migran dengan baik. Penulis menyarankan untuk penelitian serupa sebaiknya peneliti mengkaji adaptasi migran dari sisi lain agar diperoleh suatu gambaran yang lebih baik dan 
utuh. Selain itu, dalam penelitian ini peran jaringan sosial terhadap adaptasi migran di daerah tujuan tidak signifikan karena minimnya interaksi migran dengan jaringan sosialnya. Oleh sebab itu, penulis menyarankan kepada migran untuk mengembangkan dan memelihara hubungan serta meningkatkan intensitas interaksi dengan jaringan sosial agar bantuan yang diterima dari jaringan sosial juga meningkat. Sementara itu, untuk membantu proses adaptasi migran, pemerintah setempat diharapkan dapat membuat kebijakan yang dapat mempermudah adaptasi migran di daerah tersebut.

\section{DAFTAR PUSTAKA}

Avin. Desember 1994. Hidup di kota semakin sulit: bagaimana strategi adaptasi dalam situasi kepadatan sosial. Buletin Psikologi. [Internet]. [dikutip 12 Maret 2011]. Tahun II, Nomor 2. Dapat diunduh dari: http://avin.staff.ugm.ac.id/data/jurnal/ hidupdikota_avin.pdf

Fadhilah AN. 2007. Migrasi dan proses interaksi sosial masyarakat migran Batak Mandailing (Studi kasus masyarakat migran Batak Mandailing, Desa Ciomas Rahayu, Kecamatan Ciomas, Kabupaten Bogor, Provinsi Jawa Barat). [skripsi]. Bogor [ID]: Institut Pertanian Bogor. 94 hal.

Fierda G. 2007. Migrasi dan pemanfaatan dalihan na tolu pada migran etnis Batak Toba (Kasus migran kumpulan Marga Aritonang di Bogor, Provinsi Jawa Barat). [skripsi]. Bogor [ID]: Institut Pertanian Bogor. 100 hal.

Frank A. Juni 2004. Proses mobilitas dan strategi adaptasi orang Tanimbar di Kota Jayapura, Provinsi Papua. Humaniora. [Internet]. [dikutip 12 Maret 2011]. 16(2):168-176. Dapat diunduh dari:isjd.pdii.lipi.go.id/admin/jurnal/16204168176. pdf

Haryono TJS. Tanpa tahun. Jaringan sosial migran sirkuler: Analisis tentang bentuk dan fungsi. [Internet]. [dikutip 10 Maret 2011]. Dapat diunduh dari:http:// journal.unair.ac.id/filerPDF/Jaringan $\% 20$ Sosial\%20Migran\%20Sirkuler.pdf

Irfan M. 2007. Jaringan sosial dan perkembangan usaha pedagang kaki lima (Studi kasus di kalangan pedagang kaki lima Minangkabau, Pasar Kebon Kembang, Bogor). [skripsi]. Bogor [ID]: Institut Pertanian Bogor. 87 hal.

Lee ES. 1984. Suatu teori migrasi. (diterjemahkan dari bahasa Inggris oleh Hans Daeng). Yogyakarta [ID]: PPK-UGM. 24 hal. (Judul asli A theory of migration . Dalam: Demography 3(1). Tahun 1996. Hal. 47-57).

Nainggolan FA. 2001. Peranan sistem kekerabatan dalihan na tolu dalam strategi adaptasi etnis Batak Toba di Kotamadya Bogor (Kasus: keluarga migran di sektor informal). [skripsi]. Bogor [ID]: Institut Pertanian Bogor. 110

Pane MD. 2004. Migrasi etnis Batak Toba dan sektor informal di DKI Jakarta (Kasus: migran etnis Batak
Toba yang berusaha/bekerja pada usaha pelumas dan tambal ban di DKI Jakarta). [skripsi]. Bogor [ID]: Institut Pertanian Bogor. 108

Pemerintah Desa Jayamukti. 2008. Profil Desa Jayamukti tahun 2008. Tidak diterbitkan.

Rusli S. 1996. Pengantar ilmu kependudukan. Jakarta [ID]: LP3ES.

Safrida. 2008. Dampak kebijakan migrasi terhadap pasar kerja dan perekonomian Indonesia. [disertasi]. [Internet]. [dikutip 20 Mei 2011]. Dapat diunduh darihttp://www.damandiri.or.id/file/safridaipbbab1. pdf

Singarimbun M, Effendi S. 2008. Metode penelitian survai. Jakarta [ID]: LP3ES

Tarigan H. 2004. Proses adaptasi migran sirkuler: Kasus migran asal komunitas Perkebunan Teh Rakyat Cianjur, Jawa Barat. [Internet]. [dikutip 10 Maret 2011]. Dapat diunduh dari: pse.litbang.deptan. go.id/ind/pdffiles/WP_47_2004.pdf.

Yusuf N. 2006. Analisis ekonomi sektor informal di Kota Tangerang: Strategi bertahan hidup dan faktor-faktor yang mempengaruhi tingkat pendapatan migran. [tesis]. Bogor [ID]: Institut Pertanian Bogor. 110 hal. 